\title{
Influences of Ernest Hemingway's Novel "For Whom the Bell Tolls" on Petro Marko's Novel "Hasta la Vista"
}

\author{
Lirak Karjagdiu \\ Associate Professor of English Literature, \\ Department of English Language and Literature, \\ University of Prishtina, \\ Street "George Bush", No. 31, 10 ooo, \\ Pristina, Kosovo \\ Naser Mrasori \\ Associate Professor of German Literature, \\ Department of German Language and Literature, \\ University of Prishtina, \\ Street "George Bush", No. 31, 10 ooo, \\ Pristina, Kosovo; \\ Corresponding author
}

DOI: https://doi.org/10.36941/jesr-2022-0043

\section{Abstract}

The reception of Hemingway's translated works in Albanian literature and culture had begun since the late 1950s, more precisely in 1957, and it had continued to grow in sixties, to reach a culminating and most successful reception in the last decade of the last century. In all likelihood Hemingway's works in Albanian literature and culture were received with warmth, curiosity, respect, admiration and enthusiasm both by readers and by literary critics, researchers, scholars, etc.In addition to the reception there are traces and evidences that Ernest Hemingway with his novel "For Whom the Bell Tolls" had influenced and incited Albanian writer Petro Marko to write one of his best novels "Hasta la Vista". This is due to the fact that both writers had gone to volunteer to fight in Spain, like many from all over the world. However, they lined up in different brigades, Petro Marko in the XII Brigade and Ernest Hemingway in the XV Brigade. They both wrote similar novels about this great historical event. Both these novels have in common some of the main themes, motifs, symbols, conflicts, events, style, etc. Therefore, using qualitative and comparative literature methods this article will attempt to shed light on the impact of Ernest Hemingway novel "For Whom the Bell Tolls" on Petro Marko's novel "Hasta la Vista" by focusing on the main similarities and differences of these two novels written by two authors who belong to different literatures and cultures on the same subject and theme, motivated by the same historical event, Spanish Civil War.The paper concludes that Hemingway's novel "For Whom the Bell Tolls" directly influenced the Albanian writer Petro Marko to write his novel "Hasta la Vista". This is because, when Hemingway recounted his experience in the Spanish Civil War in his novel "For Whom the Bell Tolls" and after the Albanian writer, Petro Marko read his novel and had direct contacts with Ernest Hemingway, he wrote his own novel "Hasta la Vista" under Hemingway's influence. As a result, Petro Marko's novel is quite similar to Hemingway's novel in terms of themes, motifs, symbols, characters, conflicts, style, etc., though there are differences between these two novels, as well.

Keywords: Comparative literature, American and Albanian literature, Ernest Hemingway, Petro Marko, novel, direct influence 


\section{Introduction}

War is considered by various scholars to be the oldest social phenomenon and one of the most ancient social professions, which will accompany humanity until the existence of this world. As such, it is a subject of treatment in various fields of human knowledge (Abazi, 2002, p. 4). History has proven so far that writers, through their literary works, are the first challengers of war and of any kind of oppression and exploitation. Therefore, they are scrutinized more by the political representatives of tyrannical regimes which in fact contribute and cause these social and human deformities and deficiencies more than any other category of the elite. Such a thing happened on the occasion of the Spanish War, when in 1936, the Congress of anti-fascist writers was held. In Spain, more specifically in Madrid, Valencia and Barcelona this Congress was held for several days in a row, which was attended by a number of well-known writers from different countries and was greeted through telegrams by outstanding scientists, artists, researchers such as: Rome Roland, Albert Einstein, etc. In attendance were also distinguished writers like: Pablo Neruda and Ernest Hemingway, from America Nicholas Guillen, from Cuba Andersen Nexø, from Denmark, Anna Seghers, Ludwig Renn and Erich Weinert, from Germany, Ilya Ehrenburg, Tolstoy, from the Soviet Union, etc. In other words, the Anti-Fascist Congress in addition to writers from Spain was also attended by writers from twenty-six different countries of the world. From Albania, Petro Marko was lucky to participate, although at a young age and still not that known even in Albanian literature. In Spain he was recruited by the international volunteers for the freedom of Spain and the Spaniards. Petro Marko's journey to Spain had lasted a long time, so much so that it reminds the Albanian readers and scholars to vicissitudes of Homer's Odyssey. This is because instead of taking a very short route, the Albanian writer had to cross the harbours of Beirut, Alexandria, Tripoli, Algeria and Marseille to reach Spain (Marko, 200o, p. 181).

Hemingway went there as a war reporter, but when he arrived he did not avoid confrontation with the phalanges, while Petro Marko went there simply as a volunteer to fight for the freedom of Spain and the Spaniards, but to also write about this significant historical event. He had gone to fight for the freedom of Spain convinced that he was fighting at the same time for the freedom of his own country, Albania, which had already begun to feel the threat of Italian fascism. The period between 1930 to 1938 represents the time when Albania was weakening economically, while its dependence on fascist Italy was increasing day by day. These events and the many vicissitudes that Petro Marko had experienced from the time of his departure to Spain until he arrives there will later serve him as a necessary and sufficient background to recount his numerous literary memoirs in prose and poetry. In addition to war, what influenced Albanian writers to write about the Spanish War was also explained by Albanian writer and intellectual, Fatos Arapi, who came up with a very interesting conclusion about Albania and Albanians: "Being a Balkan country, Albania is first and foremost a Mediterranean country and this means that the economy, the psychology of our people, culture and all history have been developed in close relations with the economy, culture and history of other peoples and countries of the Mediterranean and as such, its general developments have been identical to the developments of other Mediterranean countries, including Spain" (Arapi, 2001, p. 6).

To investigate the traces, reception and eventual impact of the literary works translated into a foreign language, the reader, critic, researcher or receiver in the role of mediator is likely to be interested in the macrostructure, fable, characters and structure of the works as well as microelements. of literary text, style, dialogues, idea, feelings and messages. Unfortunately, the "paratext", which means prefaces, afterwards, translator's notes, reviews, genuine analytical articles and papers and other serious studies, have not closely accompanied Hemingway's works in Albanian language. Apart from some journalistic writings, two or three critical treatises and a preface on the reception of Hemingway's work in Albanian his works had not been accompanied by a quantitative and qualitative "paratext" and research articles on Hemingway's influence in Albanian literature and culture. The first mediators, those who make it possible for a literary, cultural and artistic work to "cross" the linguistic boundary, were some talented and outstanding Albanian literary translators, 
such as: V. Kokona, A. Kristo, P. Misha, S. Drini, P. Qesku, Guskiqi, S. Gjomena, J. Kurti, while some of the most distinguished researchers, scholars and literary critics, who wrote about Hemingway in Albanian literature are as follows: Abdullah Karjagdiu, Hasan Mekuli, Ramiz Kelmendi, Fadil Bajra, Pirro Misha, etc

However, the reception of an author or his works in a literary tradition is not the same as his influence, even though reception might also incite and lead to influence (Stallknecht \& Frenz, 1973, p. 92, 93). Therefore, whenever we can ascertain, on the basis of a comparison between two texts, that the qualities of the one work have been inspired by the special character of the other, we may properly speak of influence. (Corstius, 1967, p. 185). This is exactly what happened to the Albanian writer Petro Marko when he wrote his novel Hasta la Vista.

Namely, Petro Marko, in the new edition and version of Hemingway's translated novel For Whom the Bell Tolls, had written a short but extremely interesting preface where he openly admits that he was influenced to write his novel by Ernest Hemingway's novel For Whom the Bell Tolls. In this preface, P. Marko, after highly praising Hemingway as a great master and expressing the opinion that this is Hemingway's best novel, concludes that Hemingway created a novel, where time is given in all its dimensions. He believes that Hemingway's novel is deeply humane and is characterized by progressive ideas, harsh realism, strong characters, completely original style, which are all together so attractive, pensive and exciting. At the end of his preface, the Albanian author admits that he wrote his novel Hasta la Vista under the influence of E. Hemingway. "When I read his novel" he claims "I was so amazed that I started writing my own novel entitled Hasta la Vista on the same subject". When it was published, I sent Hemingway a copy, where I wrote: "Deeply inspired by your novel dedicated to the American volunteers who fell in Spain, I wrote this modest novel, consecrated to the Albanians who died fighting in the Spanish Civil War." After two or three months, I received a postcard. I opened it and read Hemingway's answer written in Spanish: "Dear Pedro, I received your novel and I would like to thank you. Alas, I cannot read it, because I do not know and understand your language. I am sure of only one thing: the writer, who loves people and dies for them, writes well..." (Hemingway, 2003, p.5). This is what Pishua and Rousseau, two well-known scholars of comparative literature, would call influence, which in fact is a subtle and mysterious mechanism through which one work stimulates the creation of another.

Hence, the article will specifically try to illuminate and analyse the similarities and differences between these two novels and the impact that Ernest Hemingway's novel For Whom the Bell Tolls had on Petro Marko's novel Hasta la Vista. The elements that these two novels have in common are some of the main themes, motifs, certain events, conflicts, etc.

\section{Analysis and Discussion}

\subsection{Two different writers on the same world historical event, Spanish Civil War}

Both novels belong to classical, Balzacian realism. This is because they have detailed and concrete expositions of the characters, setting places, events and basic conflicts of the characters. The characters are depicted first visually and externally and then internally and psychologically; the events are described in details, without overlooking character's social problems. The dialogues, the external descriptions and the changes of the narrative points of view are proportional and in keeping with the best practices of the realism novel (Zyberaj, 2003, p. 20). For the poor tradition of the Albanian novel of that time, a model such as Hasta la Vista was nonetheless a good start for a new narrative school. The novel is a product of P. Marko's deep knowledge and experience of that Spanish reality and many facts and phenomena that have to do with various aspects of the Spanish Civil War (Qosja, 1981, p. 557). According to Dr. Sadri Fetiu: "Through this novel Petro Marko marks the beginning of overcoming the chronological form of recounting and depicting historical events, which was done thus far by Albanian novelists, who in their works explored true historical events of the periods before and after the National Liberation War" (Fetiu, 1979, p. 52). Moreover, Dr. Agim Vinca, 
estimates that through this novel: "P. Marko brought to the Albanian novel of the 5os not only thematic freshness, but also new structural, compositional, linguistic and stylistic elements, thus becoming the inspiration of new trends and processes in the later development of Albanian novel" (Vinca, 1995, p. 146). On the other hand, Hemingway too, as a great, vocal and articulate representative of a remarkable literary tradition, who was familiar with all the great achievements in the modern novel, starting with James Joyce, Virginia Woolf, William Faulkner, etc., and continuing with other great and innovative novelists, has preferred simple narrative techniques avoiding deep philosophical reflections, inner monologues and stream of consciousness narrative techniques. Moreover, in For Whom the Bell Tolls, Hemingway chooses not to use even some of his most original achievements he employed in his earlier works: suggestive, implicit and straightforward dialogue, symbolic connotations of natural landscapes, the unfinished epilogue and the unwritten end. He displays and depicts the rich and turbulent internal state of Robert Jordan through the clear dialogue of the protagonist with himself, a situation which is described through the following phrases: "R. Jordan said to himself..., and himself told R. Jordan...” (Hemingway, 1995, p. 188).

In this respect the two novels are quite similar because both authors demonstrate the same artistic and literary authenticity, candidness and efficiency. Suffices to explain that Hasta la Vista has all the elements of a historical novel and furthermore could be considered a model of the historical novel given that at the centre of the attention of its narrative is a historically world important event, Spanish Civil War, and characters and the author is ever present and comprehensive.

In formal, structural and narrative parameters the two novels demonstrate simplicity, accuracy and functional perfection. But the novels do not have the same dynamic, the same expressive force in the most relevant neuralgic points. The protagonists of $\mathrm{P}$. Marko's novel have little psychological insight and complexity, little social and human significance compared to E. Hemingway's heroes. Even at the get go in their epigraphs both authors reveal different intentions, P. Marko promises a homage novel for Albanian volunteers in Spain, while Hemingway vows to elaborate in prose a poetic and philosophical view of the poet John Donne, namely he undertakes to give an account of the tragic intertwining of the fate of each man with the whole human condition:

"No man is an Iland, intire of itselfe; every man
is a peece of the Continent, a part of the maine;
if a Clod bee washed away by the Sea, Europe
is the lesse, as well as if a Promontorie were, as
well as if a Manor of thy friends or of thine
owne were; any mans death diminishes me,
because I am involved in Mankinde;
And therefore never send to know for whom
the bell tolls; It tolls for thee.." (Hemingway, 1995, p. 4).

Hemingway uses the Spanish Civil War as an opportunity and an enormous experience to make his discoveries about human nature. He does not make a distinction between two types of killings: the martyrs, ours, on the one hand and the others, the enemies, on the other hand, unlike Petro Marko, who even in the epigraph of his novel makes this distinction and announces this black and white, straightforward and explicit attitude.

The hero of P. Marko's novel Hasta la Vista, Gori Gjinleka is a static character, who remains a character on a dead end, not fully developed. He volunteered to participate in the Spanish Civil War in an event of continental importance, though he lacked a strong, all-encompassing knowledge and experience about the world. The world for him consisted of only communist, proletarians-brothers and bourgeoisie enemies. He does not develop psychologically and mentally, he only gives himself up to the international-communist utopia and surrenders himself to the leaders of the revolutionary movement. The character Gjinleka has come to symbolize the essential feature of the crowds, the sincere submission to superiors, the reverence for the cult of the leader-commander and the blind worship of his political group. The cult of Professor Tomorri and the cult of communist commissars 
in general is a model of that submissive idolatry and fascination of the masses with the high communist leadership that would culminate in Albania years after Hasta la Vista was written. Indoctrination, dogmatism and philosophical and political shallowness are not attributes of the conscious aesthetic characterization of the hero by the author, but are traits of self-imposed restrictions of the author, certainly incited and induced by editorial pressure, self-censorship and preconceived practices in force back then in Albania.

The above-mentioned inequalities are a reflection of the cultural and literary formation of the two authors, but, at the same time they are a consequence of the discrepancies between the respective cultural-political environments. For Hemingway we can be satisfied with the following assessment of one of his harshest critics, Paul Johnson:

"At first glance Ernest Hemingway is not easily recognized as an intellectual at all. On closer inspection he is not only seen to exhibit all the chief characteristics of the intellectual but to possess them to an unusual degree, and in a specifically American combination. He was, moreover, a writer of profound originality. He transformed the way in which his fellow Americans, and people throughout the English-speaking world, expressed themselves. He created a new, personal, secular, and highly contemporary ethical style, which was intensely American in origin, but translated itself easily into many cultures. He fused a number of American attitudes together and made himself their archetypal personification, so that he came to embody America at a certain epoch rather as Voltaire embodied France in the 1750's or Byron England in the 1820's" (Johnson, 1989, p. 1).

Innate talent, stylistic perfectionism and a life filled with extraordinary experiences are what distinguish Hemingway. But we would add that he was an extraordinary reader. From an early age he had read and analysed all the masterpieces of literature, arts and philosophy that had been created and written in his country, in Europe and in Russia. However, although he was part of this great tradition, Hemingway decided not to write based on tradition but against it, employing radically innovative, original and legible style. In addition, he had a huge experience which he recounted in his novels, including Hasta la Vista.

On the other hand, in P. Marko's case it is his life experience until 1944 that had a huge effect on his writings because after that his familiarization, enrichment with western culture and natural intellectual developments becomes really impossible. Hence, because of the communist regime in Albania, his experience as a participant and witness of great events, instead of being an advantage and a raw material for major literary works, turns into restraint, adversity and a strong motive of silence and concealment of his real outlook, convictions and opinions. The first successful and promising P. Marko's literary works in literature are not welcomed but instead become a cause of his persecution and all-round violence. The opposite is true of Hemingway. This is because in Hemingway's literary beginnings Ezra Pound upon expressing his conviction that Hemingway writes brilliantly and is the most stylistically talented prose writer, strongly influenced and convinced Ford Maddox Ford to open him the path for a new literary career. Hemingway shows his gratitude to Ezra Pound by rescuing him years later from the death penalty.

Looking at the concrete circumstances where and how E. Hemingway and P. Marko lived and worked, we can notice the inequalities between the two authors, through their works, as a result of the respective literatures, cultures and traditions. Cultural tradition could not offer more to the talented P. Marko because for the cultural horizon of communist Albania at that time, the publication and presence in the library of a novel like For Whom the Bell Tolls was considered unnecessary and undesirable. Even in the decades that followed, Hemingway's and novels of other foreign authors were censured, banned and some of them were even legally punishable. Moreover, it is worthwhile to point out that in fact as a complete book Hemingway's novel in question reached the Albanian reader only by 2002. 
Whenever a researcher is given the opportunity to compare a literary work with another, regardless of point of view he approaches, he will unavoidably compare various elements of those works. In this case, the two important novels, one of the American literature For Whom the Bell Tolls by Ernest Hemingway and the other one Hasta la Vista by Petro Marko, which belongs to Albanian literature, have similarities and differences and other common and special elements.

In P. Marko's novels, discourse is a motivating element, which is sometimes personal and emotional with very diverse metaphorical language. All Marko's works are interconnected and thus all his books constitute a sort of integral system, which narrate or display similar issues and elements from different perspectives. They communicate with each other, connect with ideological, thematic and discursive bridges and they contain more or less similar characters, changing only their names, events, etc. He structures the text on the principle of thematic code, each end becoming a new beginning. Thus, the themes he explores are personal, national and sometimes universal. Hemingway's works on the other hand are structured in an ironic and sarcastic way, with short, indirect sentences, sometimes with idiomatic discourse, ironizing the futility of war, death, suicide and anxiety.

Authors of both novels through their original ideas reveal the multiple importance of the Spanish Civil War. Through their works they remembered, praised and admired the solidarity of many fighters and soldiers of different countries who gave their contribution by being near those who needed support and help to fight against a world invader, against the Nazi-Fascists. The first, Hemingway, through his novel, tried to realize the initiative and support all his compatriots, during the time of the terrible war, who were ready and willing to sacrifice themselves for the good of humanity, only to come to the aid of those in need and to respond to the destructive fascism. So, the very idea of the author realized in the work moralizes the heroic gesture of the participating characters and through them reflects all the national support and backing of his entire country to the cause of this war. The initiative of many writers who have written various literary works about the Spanish Civil War, especially Ernest Hemingway's initiative, has influenced the prominent Albanian writer Petro Marko to do the same. Namely, he highly appreciates this initiative, this valuable work, which becomes a push, a motivation and a model for him to dedicate a literary work to all Albanian volunteers who took part in the Spanish Civil War.

The development of the main theme of Spanish Civil War by both writers is realized through the similar narrative. The description of events and situations in the development of battles is given in details by both writers. In E. Hemingway's novel the theme is explored with the description of situations and events through characters, which are not so numerous, and the major theme and events mainly revolve around the protagonist of the novel Robert Jordan, who is portrayed as a missionary, whose mission is to blow up the bridge. On the other hand, Gori Gjinleka in P. Marko's novel Hasta la Vista is a character, who sets the plot in motion, because he acts in many situations, he is very cooperative and dear to others even though he is not charged with any special task or mission like Hemingway's protagonist, Robert Jordan.

Since the themes of both novels deal with war, the reader goes through and experiences sensitive situations and moments, both emotional and spiritual, especially in certain instances. In both novels, in addition to the theme of war the theme of love is also explored. This way, the lives and love affairs of the protagonists are described with sensitivity and emotionality, which makes them feel motivated and it gives them courage and strength to accomplish tasks and mission they have set for themselves. In E. Hemingway's For Whom the Bell Tolls Robert Jordan falls in love with Maria, while Gori Gjinleka in P. Marko's Hasta la Vista falls in love with Anita Gonzales. Both Maria and Anita are witnesses and survivors of the sad and tragic events of the war. While Anita escapes as the only survivor of her entire family, Maria is a victim because she is captured as a prisoner of war, thus their destinies intersect at one point as they both have a bitter fate (Zyberaj, 2003, p. 35).

The theme of love is explored by both writers but in a different way. If in Hemingway's novel 
love appears and develops gradually and is ever-present, in Petro Marko's novel it has another temporal and spatial dimension. That is, love in P. Marko's Hasta la Vista emerges by chance but is nurtured by the sincerity of the past and the fidelity of the future. Gori's love for Anita, aspires to be longer lasting. It is more idealistic and contains a purpose behind it, which is not that evident in Robert Jordan's relationship with Maria. Hence, to his last love, Maria, he was not loyal in the physical sense, because Robert had previously had relationships and affairs with women, but in the spiritual sense, because he had felt with Maria the real pleasure of loving someone.

Both protagonists and their girlfriends seem to express their feelings freely and strongly. Gori Gjinleka and Robert Xhordani appear as true protagonists, worthy of being loved and not afraid of the war, well aware of the goals and missions they have set for themselves to accomplish and continue with dedication and determination the fight to the end. In addition to the two main protagonists, we also have other characters which perform their actions, have dialogues, move the story along a plot line within the novel and give value and contribution to the fulfilment and completion of the novel substantively.

Maria's fate in E. Hemingway's For Whom the Bell Tolls is almost identical to Anita's fate in P. Marko's Hasta la Vista. The differences in destinies of the two characters are so small and insignificant that they are not worth noting. Moreover one has the impression that their similarity, along with some other motifs like that of the dilemma of the first murder of the enemy, is more a result of Hemingway's influence on P. Marko than of a casual correspondence and similarity of these two novels.

In addition, in these two novels we have images that are quite similar to each other, especially when it comes to the atrocities of the phalanges against the defenceless population, which were oftentimes carried out against innocent people only because some of them either supported the movement or sympathized it. Other motifs that are similar in these two novels are the destruction of the bridge by Xhemail Kada in P. Marko's Hasta la Vista with the demolition of the bridge by Robert Jordan in E. Hemingway's For Whom the Bell Tolls, which is the leitmotif of the latter and around which almost all other events revolve.

The adoption of orphans is a motif we encounter in both novels. Pilar's love and care for Maria until Robert arrives is almost akin to the French colonel's paternal care for Anita, whom he had adopted as his own daughter, following the tragedy of the war.

The pain of the murders different characters are forced to commit is another motif we come across, which is similar in both of these novels.

\subsection{Dramatic, heroic and tragic events and scenes in both novels}

In Hemingway's For Whom the Bell Tolls, especially in the beginning of the novel there aren't any attractive and intense events by contrast in Petro Marko's Hasta la Vista the drama appears from the get go. The authors do not always move along the same narrative lines by departing from the main events and by supplementing them with retrospective events. This happens in both novels, which proves the creativity of both authors.

It is clear that both novels For Whom the Bell Tolls and Hasta la Vista were written for the same purpose to represent and admire the struggle of various heroes who participated in the Spanish Civil War. However, the approach of both writers their point of view and the presentation of situations and dramatic and tragic scenes differs. While in Hemingway's novel we have less drama, because the characters appear huddled in one place, in a cave improvised by the writer's imagination, in P. Marko's novel we have more tense and dramatic situations, we have the changing and shifting of places and locations of the characters and the changes of the situations and the intensity and pace of fighting.

In For Whom the Bell Tolls Hemingway through a group of characters, participants in the main events and developments, interlaces all the events and scenes of the novel from beginning to end. The design of plans and strategies of action for war is done mainly in a shelter, in a cave where the protagonists feel safe. We also have cases when the characters, through the author's narration, 
become part of dramatic actions, part of observations and foreshadow their visionary ideas to reach their main goal, the destruction of the bridge. The efforts of the protagonists are relentless, well thought out and studied. Proper preparations are made, every event that can happen is studied and finally the results are positive, because the objective is met and the mission is accomplished. The main protagonist, Robert Jordan, considers his vision for his mission, the demolition of the bridge, as an attack to the weakest point of the enemy. The novel is characterized by numerous reminiscences in the form of long flashbacks of events from the lives of various characters, mainly of Robert but also of others through stories, dialogues, anecdotes and internal monologue. This way the narration results in a wide range of focalization which is a very effective technique in expanding the range of narrators and settings in the novel. Consequently the novel is full of inner monologues of the characters and dialogues which are extremely simple though very significant because they help us understand the complexity of the subject, themes and characters of the novel, who are much more elaborate than Marko's characters, especially in psychological terms (Mesent, 1992, p. 73).

On the other hand, in Petro Marko's Hasta la Vista there are more movements of all the characters and there are more frequent dramatic situations full of emotions. In this novel it is not only the main protagonist, Gori Gjinleka, who is at the centre of attention, but also other characters, such as: Asim Vokshi, Xhemail Kada, Dragushi, Ramizi, etc., because in a way the author wants to reflect the contribution of all these Albanian heroes, some of whom even died fighting against fascists in the Spanish Civil War. Therefore, the depiction of their participation and contribution to the war is excellent, which can be best noticed when they give moral support to each other by taking special care for each other and by feeling and expressing an even greater closeness. Dramatic and heroic situations are tense and emotional, their adaptation as well as authorial narratives arise the readers' curiosity and sensitivity, making the author part of that world in order for them to show solidarity with characters and their situations as much as possible. Fighting takes place in different places and locations. War flares up and the fighters who respond to different atrocities and attacks must be on the front line. What is noticed in Petro Marko's novel is also the tone of emotionality, especially when he describes Albanian warrior characters by attributing them the typical traditional features, such as: fearlessness, bravery, stoicism, solidarity, etc. (Zyberaj, 2003, p. 38).

Although both authors wrote about the same war, each of them has presented this event and developed the themes and events from their own perspectives, still there are events in novels which are similar, such as the bombings of airplanes. These are the most dramatic and tense events where climax is reached and hence they are described by both authors as terrible, gruesome and horrible. Sometimes these moments may be too disturbing for the ordinary reader, however they are to be expected given that war is the dominant theme of both novels.

It should be noted that apart from the creativity in describing dramatic, heroic and tragic scenes both authors although favouring and elevating their protagonists by highlighting their courage and heroism, they also show them facing difficult positions and situations while carrying out their obligations and missions. This is precisely how E. Hemingway depicts the protagonist of his novel when, during the most critical moment of accomplishing his mission, he breaks his leg, and then he stands in front of the enemy, which is a highly sensitive situation, quite touching for the reader, but in a way again makes you feel proud for his manly attitude, courage and heroism. In a like manner, the protagonist of P. Marko's novel, Gori Gjinleka, from the very outset of the novel experiences dramatic and tragic events, when he is injured. Because of the wounds received he faces many problems for several weeks, but he manages to survive and overcome the pains and sufferings and to get back to his friends in the front.

\subsection{Characters, heroes, guerrillas and their dilemmas in E. Hemingway's "For Whom the Bell Tolls" and P. Marko's "Hasta la Vista"}

In both novels the character modelling stands out, including the protagonists, who were based on real people with the only difference that Marko models the protagonist, Gori, completely on himself 
while Hemingway does not. As an illustration, in Hemingway's novel, researcher Robert Martin (1987) has identified Robert Merriman, an American volunteer with the rank of Major in the Abraham Lincoln Battalion of the International Brigades, as a model for the novel's protagonist, Robert Jordan, and the same goes for Maria, Pillar, El Sordo who are modelled on real people. Also, according to Jerzy Krzyzanowski (1962, pp. 69-74), Golz was based on Karol Swierczewski, a Polish colonel in Russian service (Martin, 1987, pp. 219-225).

The approach to the characters in Hemingway's novel, whose number is not so small, is facilitated by the fact that they, in terms of dynamic development, are categorized in the first and second group characters. The characters of the first group are the ones of the mountain events, especially the characters related to Pablo's guerrilla group. The characters of the course of other events, respectively the actions in Madrid and at the front or elsewhere, belong to the characters of the second group. It goes without saying that the most elaborate and characteristic character of the first group is Robert Jordan. He is a man of action. He enters a dangerous mission with joy. Like Hemingway's other characters and heroes and in keeping with Hemingway's code hero, he seems to realize that dying with honour is even more important than living well.

However, unlike other Hemingway characters, R. Jordan believes in an ideal, a cause and an ideology (Cooperman, 1964, p. 98). The cause he has come to fight for is the "government of the people" in Spain. R. Jordan's liberal political views had motivated him to leave the University of Montana, where he taught Spanish in order to fight against the enemies of the Spanish Republicans. While most liberal intellectuals showed a willingness only to denounce in words the rise of fascism in Spain, R. Jordan actively defends his political views.

On the whole, R. Jordan is a dynamic character, smart, inventive, courageous and determined. He had so much self-confidence and ingenuity that he could easily cope with even very complex situations. It was these qualities that helped him survive in the assigned role of explosive expert and partisan engaged behind enemy lines. He was ready to accomplish his mission, although before the action he had begun to have some doubts even for his ideals that had brought him to Spain. He was gripped by various contradictory concerns and ideas and unexpected dilemmas. For R. Jordan, commitment to ideology was important at the beginning, but not at the end of his mission. He realized that the cause he was fighting for had become less interesting and that perhaps any such cause would sooner or later be weakened. He was transformed from a believer and idealist into abstract ideas into a believer in the importance of the real life. Love with Maria brought him joy, happiness and optimism for some time, but also pain and regret because of the necessary separation from her, due to his mission and his bad luck. His affair and relationship with Marie served him "as a means" to carry out his mission. His relationship with Maria helps him understand the world from which he had come and to reconsider his previous worldviews and his previous way of life. In the end, R. Jordan's horse was shot by enemy bullets, so the horse fell on him, breaking one of his legs. However, he decides to fight as he sought to protect his comrades and to enable them to retreat to a safer area. It was obvious that there was no other way out and all guerrillas had to move on, except Maria, who did not want to be separated from R. Jordan. However, Maria too, in a way is forced to part with him after Pillar and Pablo beg her and persuade her to leave. The wounded R. Jordan, does his best not to lose consciousness and to kill as many enemies as possible. He remains in combat position with a machine gun, fighting against the enemy and enabling comrades and Maria to escape. So in the end, he is killed while defending his comrades (Auer, 1986, p.5).

The character of Pablo is also a dynamic character. He is the leader of the guerrilla group, is quite interesting, not only because he often gets drunk and undermines the role of the commander, but also because his behaviour is full of unexpected contradictions (Waldhorn, 1973). Once he was a completely different Pablo, who like R. Jordan believed in the cause of the Republic. However, unlike R. Jordan, Pablo was able to carry out ruthless actions and acts. Now, he is a disillusioned guerrilla leader. He no longer believes in the cause for which he fought and prefers to survive, roam and hide in the mountains, without helping the war at all. Such behaviour cannot only turn him into a saboteur of war actions, but also a harmful and dangerous person. Thus, Pablo sometimes appears as 
a real warrior and sometimes as a completely different Pablo, who also confused R. Jordan. Most likely, all these weaknesses are caused by his excessive drinking, fatigue, giving up the life of comfort and perhaps even by the remorse of conscious for the crimes he had committed against the enemies.

In addition to Pablo, one of the characters with a considerable role is Pablo's girlfriend, Pillar, the real leader of the guerrilla group, although the role of commander at the beginning of the novel was played by Pablo. She is vigilant, aware and fearless in her duty and has special respect for R. Jordan, as a guerrilla warfare expert, but has no respect for defectors, traitors and cowards. Although, female from a rural patriarchal family, she has a special role and contribution in guerrilla warfare and is an excellent fighter. She can carry any kind of weapon like men, she knows how to use them, she uses the machine gun skilfully and she is the commander of the guerrilla fighters. She is rude and determined both in speech and in action. She also hates, underestimates and insults cowards. Although, as a woman she was not extremely beautiful, she had a noble spirit and love experiences with other men in the past. She gets along very well with Maria and feels a strange love for her. She likes the sincere love between R. Jordan and Maria. With her candid and manly character, she insults Pablo, when he returns repentant of his defection, then forgives him and loves him as before. Unlike Pablo, Pillar emphasizes that she is a loyal and true warrior of the Spanish Republic. On this occasion, she is like R. Jordan, who has the same confidence in the Republican movement. Pillar, who is wise and has a generous spirit, knows how to read the fate of people and impose her respect on men. Upon looking at R. Jordan's palm, she sadly announced his death.

Maria is a static character, she is a young Spanish woman who was rescued by Pablo's group when she stopped and shot at the enemy train. Since then, she was part of the guerrilla group. Maria has its importance in the novel because it is the main cause of the development of R. Jordan's character. She as a heroine (character) does not transform much. From the first meeting with R. Jordan, she fascinates him. She desperately needs a man who would take care of her and treat her with respect, courtesy, understanding, gentleness and sophistication. She is traumatized, so she still worries about the anxiety of the past or the brutal rape by the nationalist soldiers of the enemy. Pillar, who has a deep friendship with her, striving for her healing and comfort, has convinced her of the philosophy according to which everything Maria has done against her will in the past has not happened or it does not matter. Realizing that R. Jordan is also a gentle, noble and kind man, Maria showed an unreserved faith and love, almost adoring him. In their unique and happy love, the loving couple experiences the happiest moments of life.

The characters of other guerrillas are mainly described through their main features. Thus, Anselmo is a "Christian" hunter, who is a simple and sincere character. As the oldest of the guerrillas, he is sensitive, gentle, kind-hearted, who even considers the enemy soldier a man like himself. Therefore, every kind of murder causes him some kind of pain, because he is a religious man. Rafael is an annoying, insecure and irresponsible guy, who considers his duties towards the war as a game. El Sordo is a leader of the neighbouring guerrilla group, who is brave, believes in the cause and is devoted to the Republic. However, he is also realistic because he does not harbour illusions about the success of Republicans. Although it is clear that the cause for which he will die, will fail, he continues to fight to the very end.

Since both novels were written by the same idea and motive, then no doubt that the features of the characters of these novels are similar in certain aspects and respects by holding the same attitudes, ideas and visions about the war mission against the enemy.

In For Whom the Bell Tolls Robert Jordan as the protagonist of the main events, appears as a missionary, who together with other protagonists has the goal of blowing up an enemy bridge. On the other hand, the protagonist of the novel Hasta la Vista, Gori Gjinleka, is also a warrior. Gjinleka is also a missionary who fights for the same goals and ideas in that terrible war, but who operates in a wider circle, and thus his fellow soldiers are more at the center of attention during certain dramatic events and scenes in the war. However, we cannot claim that Gori Gjinleka is not without challenges, because he is injured and hence he suffers both physically and emotionally by staying away from his friends for several weeks. In terms of the war mission, Robert Jordan, is militarily trained. He goes to 
war with a purpose and slowly manages to accomplish his mission, while Gjinleka emerges more as a protagonist and as a volunteer, who participates in war to support the right cause, and as a character who is challenged in different situations, obstacles and confrontations.

Andrea, another character in P. Marko's novel Hasta la Vista is a young anti-fascist, patriot and idealist fighting for the future of his homeland and all the countries involved in the war. He is above all a cosmopolitan. Because of his resistance and fight against enemies, he is caught and sent before a foreign judge in his hometown. He has been accused of violating the integrity of the state! However, he has an interesting and meaningful answer to the accusations against him:

"I am involved in politics, thus I am accused because of my political convictions and activities... I want you to state here the justice of which country do you represent and defend: the one of Italian state or Albanian state ...After the translator finished, the prosecutor, reacted angrily: - Honourable Judge. We are dealing with an anarchist ... a sophisticated one ... and hence should not be allowed to violate the principles of our justice. Nevertheless, the Presiding Judge asked him to sit down. Then the prosecutor became even more agitated and outraged" (Marko, 2002, p.92).

When it comes to the Albanian novel Hasta la Vista we must emphasize the fact that through characters like: Asim Vokshi, Xhemail Kada, Dragushi, Fatosi, and their manly and military determination as warriors with virtues and stable character, P. Marko strove to reflect Albanian courage, bravery and solidarity. There are many scenes and emotional moments in the novel when the brave aforementioned Albanian protagonists appear on the front line in front of the enemy and die courageously and bravely without being afraid at all. So, all these heroic scenes are described with an elevated emotional tone by the author, but the readers too feel emotional about them and they even identify them as patriotic and heroic acts, carried out by Albanian heroes (Zyberaj, 2003, p. 42).

However, not all the characters in Hasta la Vista are described as brave and patriotic. For example the character of xha Kola is a diametrically opposite and a very mysterious character because he is almost always among warriors, but mainly joins them in parties, dances and amusements carrying out immoral affairs. Xha Kola represents those weak and debauched characters of the society. They are unstable, volatile characters who lack human morality.

Similarly in the other novel For Whom the Bell Tolls, not all the characters are liked and to the satisfaction of the reader. Some of them are blackmailers who do not obey their superiors' orders, but rather want to act according to their own mind and simply do not want superiors over themselves. Such is Pablo. A character who knows how to complicate matters, knows how to change the direction of a dialogue and ideas of other visionary characters in order to achieve his goals. He possesses physical and tactical skills, which do not suit most other protagonists, because he has diametrically opposed views, attitudes and opinions from most of the other characters. Sometimes Pablo is a hypocritical character because on the one hand he so openly opposes the idea and vision of R. Jordan, and on the other hand behind the scenes he tries to realize it. We do not deny the fact that even in Hemingway's novel we have characters which are portrayed as real heroes, who carry out their missions with bravery and dignity. Among them are: Anselmo, Pilar, El Sordo, Augustin, etc.

\subsection{Bridge semantics}

Bridges in antiquity served to connect the Hellenic shores with the barbaric ones on the west side, the shores of Greece and Rome, Rome and Constantinople, the Vatican and later Islam. They continue to play this role still, but now for connecting different cultures, nations and religions, again being the meeting points of European, Slavic-Orthodox and Turkish-Arab civilisations, which are represented by the respective religions: Catholic, Orthodox and Islamic, which coexist within the Albanian nation with a wonderful harmony. This must have been the reason why the Albanian bishop Fan S. Noli, born in Adrianople, a Prime-minister of the first democratic government in the Balkans, in a country with a dominant Islamic population, who died in America, wrote the following flag hymn: 
"Flag that gives birth to St. Constantine,

Reconciles Islam and Christianity,

Proclaims brotherhood between religions,

Generous flag of Humanity" (Noli, 1988, p. 73).

In both novels, bridge is the main common motif and symbol of hope. The Bridge, the Tower of Babel, the Trojan Horse, the Great Wall of China, the Pyramids and the Berlin Wall are the great buildings of mankind which have attracted the attention of many writers. The reason for this interest can be explained by the fact that humanity, throughout the history of its development, has put efforts to humanize the whole world around it, including the material world. As a result of these attempts, bridge in the Albanian culture has special semantic and symbolic function.

The motif of bridge in both novels has similarities and differences. The first difference between the bridge in P. Marko's Hasta la Vista and E. Hemingway's For Whom the Bell Tolls is that in the former one the hero, Xhemail Kada, both builds and destroys the bridge while in the latter one the bridge is only destroyed. These two are different actions, but both are permeated by almost the same anxiety and we have the same drama which is reflected in the soul and psyche of the characters of both novels.

The act of construction in P. Marko's Hasta la Vista is done with the aim of creating physical conditions to connect people, while the destruction, as in the novel For Whom the Bell Tolls, becomes the purpose of isolating evil. Although opposite actions, they have a common goal: the preservation and development of the humanity.

The phenomenon of the bridge with two opposite acts within itself (construction - destruction), but with the same purpose differs when it comes to time. Construction has a longer time span and the intended mission through construction is also very long, while demolition requires shorter time (several times shorter) than construction and its purpose is limited to isolate evil only for a short period of time. Both cases are accompanied by a measure of anxiety and suffering that is done for the good and betterment of humanity

Murrash's wife accounts in P. Marko's Hasta la Vista, after her husband's tragedy, of his last night spent with her, testify to the same anxiety Robert feels on the last night before he destroyed the bridge. The silence of one completely coincides with the silence of the other and, in this way a condensed emotional situation is created with a tendency that leads to the philosophical resonance of the moment in which the protagonists live. This is especially true of Hemingway's novel.

When Maria asks to talk about the next day because she wanted to understand Robert's mission, he strongly opposes and stretches himself out inside the garment, laying down calmly with his cheek on her shoulder, and placing his left arm under her head. He believes that best is not to talk about either tomorrow or what happened today because he considers that they are not supposed to only talk about losses and to be content with their fate (Hemingway, 2003, p. 283). Here we have a thickening of anxieties, with the only difference that in the first case we have the anxiety of what tomorrow will bring while in the second the anxiety of how the bridge will collapse. This was the semantics that the bridge radiates as the edifice of human activity both physically and spiritually, and for this reason, (for the purpose of connecting the shores) for thousands of years, it has continued to have its advantage in relation to all other buildings that man has conceived and built.

The determinism that can be felt within Robert's attitude that one has to accept and live with his destiny has nothing to do with fatalism. Moreover, it should not be understood as a lack of interest in what tomorrow will bring. But, first of all, it must be understood as Robert's readiness to stay and not to avoid in any way and for any moment the confrontation with what tomorrow may bring, even death. And of course, he being aware of the degree of danger of what he was going to do, and the reading of fate in his hand by Pilar, were two elements from which, quite easily, he could guess what would happen tomorrow. But he hides it, because after all, even if he showed it to Maria, what good would it do him? 


\subsection{But which are the main differences?}

The differences that can be encountered while reading these novels are conditioned and stem primarily from the different origins of the writers. Namely, Ernest Hemingway and Petro Marko are two distinguished writers who come from different countries and belong to two different literatures and cultures. They were formed in completely different environments and circumstances and the motives which make them go to the Spanish Civil War were completely different.

The first difference has to do with time, within which the events of these two novels take place. In Hemingway's For Whom the Bell Tolls the time frame of events extends within three days, while in Hasta la Vista there is a longer time span, events last for years.

There are also differences as regards the development of the theme of war. Hemingway paid attention to guerrilla warfare so much that it even overshadowed the events surrounding the wellorganized war in the military sense. However, this does by no means decrease the importance of it, even though it seems to be side-lined by the author. In contrast, Petro Marko focused on and dealt with large organizational military formations, which had come as a result of the maturation of this international movement against fascism.

War in these two novels also differs in social and psychological aspect. If we were to try to summarize all the differences in a few sentences, we would say the following: In Hemingway's novel, the idea of war prevails and his approach is: If we cannot be good friends, then we must strive to be good enemies while in Petro Marko's novel the attitude toward war is: We do not want war, but we do not avoid it when it comes to protecting our freedom and our rights. If we were to try to decipher and comment further on these opinions and perspectives, then we think that behind Hemingway's attitude: If we cannot be good friends, then we must strive to be good enemies we have no attempt at moralization, but for the humanization of relations between people even in extraordinary circumstances such as war. While in Petro Marko's novel efforts for humanization are present but are not elaborated with the profundity that literature as an art allows and enables.

Idealism is another common element that characterizes the protagonists of both novels, that if compared it is a bit difficult to ascertain in which novel this element is stronger. In Hemingway's novel it is present, but it is a bit more difficult to trace and investigate it, because it is so successfully hidden, that even for the sharpest eye and the clearest mind it remains stashed and concealed, but that its presence and significance is felt by subtext. Robert Jordan, based on some other facts, especially historical, was not a man who may have been driven to join the war in Spain by social hardships and the danger of fascism to his homeland. Most likely he should have had good living conditions in his own country, but he still went to Spain to fight for the Republican cause. Perhaps he believed in John Donne's saying: "No man is an island, entire of itself; every man is a piece of the continent, a part of the main." Therefore, the tolling of the bells for the atrocities and murders that took place in Spain had terrified him to such an extent that he couldn't just sit and watch something so dreadful and horrific happen.

And above all, there is a conceptual difference between how Ernest Hemingway and P. Marko see the solidarity of people. P. Marko, being a follower and supporter of the left ideology, which at the time was completely understandable, in his novel conceives the unification of the people in the spirit of "proletarian internationalism", which is narrower than the concept of unity and solidarity that can be noticed in Hemingway's novel. Unlike the "proletarian solidarity" that is felt and aspired by the author of the novel Hasta la Vista, in the novel For Whom the Bell Tolls the concept of Americanization dominates and is considered the best approach. The first still existed as an idea that had begun to spread almost throughout Europe at that time, while the second was established as a state regulation on the transatlantic continent. When we say that the first was narrower, it means that this concept included only certain parts of society, while the second included the whole of society in its entirety. In addition, the development in later history proved that the second concept was more successful and came out triumphant in many ways and aspects (Zyberaj, 2003, p.72).

This is a detail that should not be overlooked, because, although seemingly insignificant and 
peripheral, it can serve as and is, in our opinion, the main element that characterizes that era and its protagonists. Otherwise, there is no way to explain the fact that the Spanish Civil War, even after World War II, and the Cold War between the Eastern and Western blocs, continues to be considered and constitutes a separate chapter of efforts of humanity for freedom.

\section{Conclusion}

When there is genuine contact and interaction between writers, there is a direct influence between two literatures that extends beyond the borders of a country and a language. A literary influence cannot exist unless an author has read another writer's 'original' text or has had direct interaction with him or her. However, proving this relationship, which is based on a clear-cut causation, between nationally distinct writers is difficult, if not impossible especially when some writers do not mention (deliberately or unintentionally) their debt, if any, to certain foreign writers or works. However, in this case, the Albanian writer, Petro Marko, was opened, candid and transparent enough to admit that he not only had direct contacts with Ernest Hemingway but that in writing his novel Hasta la Vista he was directly influenced by Ernest Hemingway's novel For Whom the Bell Tolls. Both authors, Ernest Hemingway and Petro Marko, wrote novels on the same world historical event, the Spanish Civil War. These novels have undoubtedly similarities and differences.

It is clear that when it comes to similarities, both Petro Marko and Ernest Hemingway, endeavoured to connect their literary works to the world historical event, the Spanish Civil War, because they both participated in this event. Both novels E. Hemingway's For Whom the Bell Tolls and P. Marko's Hasta la Vista were written for the same purpose, to represent and admire the struggle of various heroes who participated in the Spanish War. Through their works they remembered, praised and admired the solidarity of many fighters and soldiers of different countries who gave their contribution by being near those who needed support and help to fight against a world invader, against the Nazi-Fascists. The development of the theme of Spanish War by both writers is realized through the similar narrative, namely the description of events and situations in the development of battles is given in detail by both writers. In addition to war as the main theme both authors have simultaneously developed the theme of love. Moreover, in these two novels we have images that are almost completely similar to each other, especially when it comes to the atrocities of the phalanges against the defenceless population. In both novels, bridge is the main common motif and symbol of hope. The adoption of orphans is another motif which is quite similar in both novels. Since both novels were written by the same idea and motif, then no doubt that the features of the characters of these novels are similar in certain aspects and respects because they hold the same attitudes, ideas and visions about the war mission against the enemy, etc.

Differences between the two authors include their socio-cultural contexts, literary traditions and periods and the languages in which both authors wrote their novels. There are also differences when it comes to writing their novels because both authors used different methods and during their creative process, they created original novels, through an artistic process with genuine systems of aesthetic and ethical values. Petro Marko and Ernest Hemingway also had divergent creative and ideological approaches in exploring themes, motifs and conflicts in their novels. Much of this is due to the American literary, historical and political great tradition, something that the Albanian tradition cannot claim due to various upheavals throughout its history. Authors of both novels employed original ideas to reveal the multiple importance of the Spanish Civil War. Another difference has to do with time, within which the events of these two novels take place. There is also a conceptual difference between how Ernest Hemingway and Petro Marko see the solidarity between characters in war. There are also differences as regards the development of the theme of war. War in these two novels differs in social and psychological aspect. Petro Marko's Hasta la Vista is characterized by a pronounced emotional strain and boundless hopes that can very easily end in disappointment, while Ernest Hemingway's For Whom the Bell Tolls is characterized by a more rational action and a greater opportunity to face the challenges imposed by war. And finally, the first 
has the tendency to completely deny the past and partly the present for the sake of the future, while the second has the tendency to defend the values of the present, primarily for their own sake and then for the sake of the future. It is based on these that the conceptual differences about the war and its development stemmed and were conditioned. The first is characteristic of the Mediterranean mentality in which P. Marko belongs as an Albanian in Spain, while the second is characteristic of the transatlantic mentality of people who are typified through the figure of Robert Jordan. On this premises, the conceptual differences about the war and its development are raised and determined. The first conceives it as a means to an end therefore one should pursue its goal as much as possible, without asking for the prize, while the second conceives it as a struggle but also as an ability that one must possess to care for people and their lives, even if he is an enemy.

We hope that this paper on the influence of Ernest Hemingway's novel For Whom the Bell Tolls on Petro Marko's novel Hasta la Vista will contribute to the deepening of Albanian and American literary and cultural ties and relations, to the better knowledge, dissemination, reading and recognition of Hemingway's work in Albanian literature and culture and to the incitement of other scholars to embark on conducting other researches on Ernest Hemingway's influence in Albanian literature and culture.

\section{Endnotes}

Petro Marko is largely regarded as one of the modern founding fathers of Albanian prose. In communist Albania, he was one of the most controversial writers. He spent many years as a political prisoner on charges of dissidence, and while some of his books were never published, the majority of them were censored and partly edited before being published. He was a Spanish Civil War veteran and a humanist. He was a prolific writer who primarily authored novels with larger political topics and universal human challenges. He also wrote children's novels. "Interviews with Myself: Clouds and Rocks," his final work, was published posthumously in 2000 and recounts his tough existence under dictatorship of Enver Hoxha. Hasta la Vista is his most well-known novel, which chronicles his experiences as a volunteer with the Republican forces during the Spanish Civil War. He began writing at the age of twenty, and his first works were published in periodicals with the help of his mentor, Ernest Koliqi. Since he was 20, his articles have appeared in journals such as Lirija, Shqipria e Re, Bota e Re, and Koha e Re. From March 1, 1936, he was the editor of ABC, a literary journal that was quickly suppressed by monarchist authorities, leading to Marko's arrest and internment.

Surrealist elements and patterns may be found in many of Marko's works. In 1991, he passed away, while in 2003 President of Albania, Alfred Moisiu decorated him with the "Honour of the Nation" medal.

Hasta la Vista is an Albanian novel written by Petro Marko in 1958. It widely encompasses the author's experience in the Spanish Civil War in which he was part of the International Brigades, Garibaldi Battalion. It is the author's first novel and the most important one because it marked the turning point in the development of the Albanian novel. The novel focuses on the war in Spain and on Albanian and international volunteers. It recounts the many battles of the past years at the front, which are described in vivid and unrepeatable language. In addition to the events of the war, there is another plotline, which focuses on the love affair between the Albanian fighter Gori and the Spanish nurse Anita.

The author of the novel admits that to write his novel he was influenced directly by Ernest Hemingway's novel For Whom the Bell Tolls.

\section{References}

Abazi, S. (2002). Psikologjia e luftës kundër luftës, Tiranë: Albpeipër.

Arapi, F. (2001). Çështja shqiptare dhe kriza ballkanike, Tiranë: Toena. 
Auer, J. (1986). Ernest Hemingway's “For Whom the Bell Tolls”. U.S: Peterson's Guides. Wang High School of Queen Hollywood.

Cooperman, S. (1964). The Major Novels of Ernest Hemingway. New York: Monarch Press.

Corstius, J. B. (1968). Introduction to the Comparative Study of Literature. New York: Random House.

Hemingway, E. (1995). For Whom the Bell Tolls. Novel. New York, Toronto, Sydney: Charles Scribner's Sons.

Heminguej, E. (2003). Për ke biejnë këmbanat. Roman. E përktheu, Pavli Qesku. Tiranë: Ombra GVG.

Krzyżanowski, Jerzy R. (1962). "For Whom The Bell Tolls": The Origin of General Golz. The Polish Review, vol. 7, no. 4, University of Illinois Press, pp. 69-74, http://www.jstor.org/stable/25776431.

Fetiu, S. (1979). Romani shqiptar i luftës. Prishtinë: Rilindja.

Johnson, P. H. (1989): "Portrait of the Artist as an Intellectual" https://www.commentary.org/articles/pauljohnson-3/hemingway-portrait-of-the-artist-as-an-intellectual/.

Marko, P. (200o). Intervistë me vetveten (Retë dhe Gurët). Tiranë: OMSCA.

Marko, P. (2002). Hasta la Vista. Roman. Tiranë: OMSCA-1.

Martin, R. A. (1987). Hemingway's for Whom the Bell Tolls: Fact into Fiction. Studies in American Fiction, vol. 15 no. 2, p. 219-225. Project MUSE, doi:10.1353/saf.1987.0004.

Mesent, P. (1992). Modern Novelists: Ernest Hemingway. UK: Palgrave Macmillan.

Noli, F. S. (1988). Vepra 1, Prishtinë: Rilindja.

Qosja, R. (1981). Parathënie e romanit “Hasta la Vista”, botimi i tretë, Prishtinë: Rilindja.

Stallknecht N. P. \& Frenz. H. (1973). Comparative Literature. Method and Perspective. London and Amsterdam: Southern Illinois University Press.

Vinca, A. (1995). Alternativa letrare shqiptare. Shkup: "Shkupi".

Waldhorn A. (1973). A Reader's Guide to Ernest Hemingway. New York: Farrar, Straus and Giroux.

Zyberaj, B. (2003). Fenomeni i luftës në romanet "Për kë bie këmbana" dhe "Hasta la Vista". Punim i magjistraturës. Universiteti i Prishtinës, Fakulteti i Filologjisë, Prishtinë, pp. 25-64. 